Chapman University

Chapman University Digital Commons

English (MA) Theses

Dissertations and Theses

Spring 5-2021

\title{
"Why Are We Still Reading About Rosa Parks?": Essential Questions for Continuation Schools
}

Samantha Mbodwam

Chapman University, mbodw100@mail.chapman.edu

Follow this and additional works at: https://digitalcommons.chapman.edu/english_theses

Part of the Adult and Continuing Education Commons, Bilingual, Multilingual, and Multicultural Education Commons, Curriculum and Instruction Commons, and the Curriculum and Social Inquiry Commons

\section{Recommended Citation}

Mbodwam, Samantha Alyssa. "Why Are We Still Reading About Rosa Parks?": Essential Questions for Continuation Schools. 2021. Chapman University, MA Thesis. Chapman University Digital Commons, https://doi.org/10.36837/chapman.000278

This Thesis is brought to you for free and open access by the Dissertations and Theses at Chapman University Digital Commons. It has been accepted for inclusion in English (MA) Theses by an authorized administrator of Chapman University Digital Commons. For more information, please contact laughtin@chapman.edu. 
"Why Are We Still Reading About Rosa Parks?":

Essential Questions for Continuation Schools

A Thesis by

Samantha Alyssa Mbodwam

\section{Chapman University}

Orange, CA

Wilkinson College of Arts, Humanities, and Social Sciences

Submitted in partial fulfillment of the requirements for the degree of

Master of Arts in English

May 2021

Committee in charge:

Jan Osborn, Ph.D., Chair

Ian Barnard, Ph.D.

Joanna Levin, Ph.D. 
The thesis of Samantha Alyssa Mbodwam is approved.

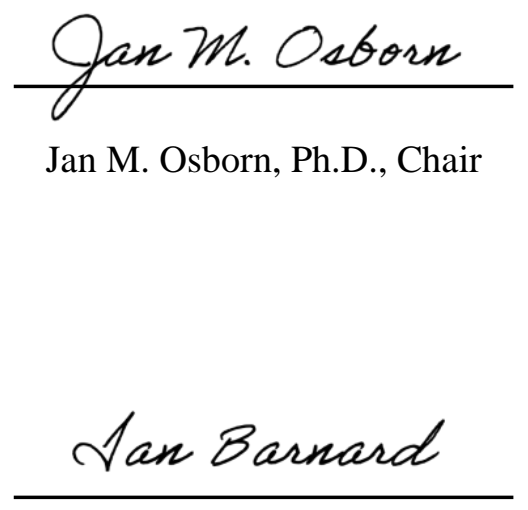

Ian Barnard, Ph.D.

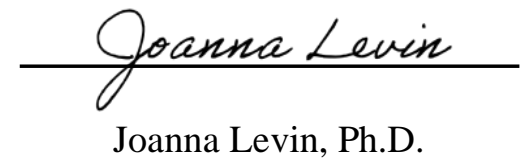

April 2021 
“Why Are We Still Reading About Rosa Parks?”:

Essential Questions for Continuation Schools

Copyright () 2021

by Samantha Alyssa Mbodwam 


\section{ACKNOWLEDGMENTS}

This thesis is dedicated to:

Jan Osborn, Ph.D., Chair

Ian Barnard, Ph.D.

Joanna Levin, Ph.D.

Justine Van Meter, Ph.D.

Sandra Batricevich-Klein

Carolyn Still

I would like to thank all these individuals for their time and dedication to this project, for without them, it would not have been possible to complete. My advisors were everything I could have asked for, and I will forever be grateful for the amount of effort they have put forth in helping me be successful throughout not only this project but for a significant part of my college career.

Thank you to Jan in particular for making this project happen. I came to Jan with a vague idea of what I wanted to do in this project, and she put in maximum effort into developing into something that I could have never have imagined it being. Without her constant support, I would have never been able to stay as inspired as I was, and my life has definitely changed for the better ever since I met her. 


\author{
ABSTRACT \\ “Why Are We Still Reading About Rosa Parks?”: \\ Essential Questions for Continuation Schools \\ by Samantha Alyssa Mbodwam
}

Continuation schools are historically constructed places of both academic and social rejection. With cultural rhetorics theory providing a context for the research, this inquiry values student stories and experiences. This IRB-approved case study analyzes continuation school education, including classroom participant-observation and interview data to explore if the current academic system is failing these children, and, if so, is failure essentially manufactured and a result of socialized oppression. Therefore, this case study provides a means to hear the voices of those students placed in a continuation school and the voice of a classroom teacher's perspective on the school curriculum and educational practice. 


\section{TABLE OF CONTENTS}

$\begin{array}{ll}\text { I.Introduction } & 1\end{array}$

$\begin{array}{ll}\text { II.Literature Review } & 3\end{array}$

III.Cultural Rhetorics Theory 9

$\begin{array}{lr}\text { IV.The Study } & 18\end{array}$

A. Teachers'Perspective 19

B. Student Stories $\quad 22$

C. The Interviews 29

$\begin{array}{ll}\text { V.Conclusion } & 39\end{array}$

$\begin{array}{ll}\text { VI.Bibliography } & 42\end{array}$ 


\section{Introduction}

When I first got my job at X Continuation High, ${ }^{1}$ I can remember the look on my mother's face when I told her I had been placed there.

"Will you be safe? Isn't that where the bad kids go?"

I shrugged off her comment with a laugh and told her it would be fine. I would, however, be lying if I said I was in full confidence of my statement and that I was not simply dismissing the matter for the sake of her reassurance. Would things really be fine?

My thoughts at the time are hard to admit to, especially since I consider myself someone that is not all that judgmental. A majority of my academic career had trained me to work with minoritized students, and, in theory, I should have been prepared to deal with the circumstances. I would also be lying if I said I had not been a bit disappointed when the district's human resources department informed me that I would be an instructional aid for the special education department at a continuation school. Had I simply been dumped where nobody wanted to go?

I tell you this not for the sake of coming to terms with my own toxic attitude but to show you that it is actually my attitude that is the problem.

We want to keep telling ourselves that these students are lazy: that this is why they continue to neglect their work at their original schools and once they are sent to a continuation school. But we have to think about how various forms of motivation work and how these students have both been internally and externally socialized before they reach these schools. Continuation schools are socially constructed to be places of both academic and social rejection.

\footnotetext{
${ }^{1}$ Pseudonyms for all names - teachers, students, and the school.
} 
Barry Kamrath, for example, concludes that "many of these [continuation school] students had children of their own, were affiliated with gangs, routinely smoked marijuana, and came from single family homes, or were even raising themselves" (Kamrath 169). Some may say that, on the surface, this statement offers some sort of affirmation for their fears: continuation school students must be more dangerous because they smoke pot and hang out with the "wrong" crowds, right? But, let's be honest with ourselves: the statistics regarding marijuana use among continuation students means close to nothing when compared to the "hard" drug use found at privileged, private schools. Private schools are just better at hiding problems because administration will conceal anything to protect their funding and public image.

Continuation schools have a clear history. They were originally based upon alternative education, (programs, "commonly defined as schools serving a majority of students that are in danger of 'behavioral' or 'educational' failure, expelled, wards of the court, or pregnant and parenting" (Dixon qtd. in Williamson 1). I was raised to take my high school education seriously; I didn't want to be sent to one of "those" schools. When I was placed at a continuation school as an instructional aid; however, my eyes were opened to the great amount of both academic and social segregation that occurs in the institutionalizing of continuation schools and the curriculum found inside of them.

My research is an IRB-approved case study analyzing participant-observations and interviews of students and the teacher within a continuation school classroom. I ask if the current academic system is failing these children, and, if so, is failure essentially manufactured and a result of socialized oppression. My case study will focus on the following inquiry questions:

- Does the school curriculum address the self-described needs and interests of the students? 
- Does the school curriculum reflect an intersection of students needs and teacher efforts to meet those needs?

- How do the continuation school students see themselves in their academic lives?

- Is student academic achievement/lack of achievement a result of institutional policies beyond the scope of individual students?

\section{Literature Review}

Discourse surrounding continuation schools is essential in terms of providing education for the most underserved students, yet the amount of scholarly discussion is far below my expectations. I am concerned with how limited the scope is in attempting to research specifics regarding continuation schools and the theory behind these institutions. I was distressed by the fact that I could review a majority of the scholarly reviewed articles on continuation schools within a few hours, yet it would take me a lifetime to skim just the titles of all the modern research conducted on Shakespeare. Why is nobody paying attention to these students? A review of the literature provides some insight.

Devon Williamson's “Legislative History of Alternative Education” educates readers on the history of the basis upon which continuation schools were founded. Williamson makes it clear that continuation schools are seen as alternative education programs designed to warehouse "failure" (Dixon qtd. in Williamson 1). This early definition of continuation schools shows that they were originally created for individuals that were considered outsiders - those who were different from students who lived under the constructions of "normality." Williamson suggests it is also generally accepted that many continuation students enter the alternative education (AE) system with more than just particular academic needs: 
AE students face a variety of additional challenges such as high residential mobility, increased dropout rates, living in foster care, and low socio-economic status ... Continuation schools as a system operate in the gap between social services provision and mainstream public high schools, serving at risk students linked-to or in-need-of resources normally outside the purview of the classroom. (Williamson 1)

This is a pattern that proved itself to be true even in the twenty-first century and is the reason why more attention ought to be given to students in continuation schools. The irony of the situation is that in the general education classroom these students are given less attention because of the assumption that their inability to succeed is due to negligence, so they are pushed out of the public high schools, as if they do not have a place among the "regular" students. Segregated spaces may not be inherently harmful to a student if it serves to actually serve their individualistic needs, but as this study makes clear, that is not always the case.

The interesting thing about continuation schools is that we all know that they're different, and we all have presumptions about the students who get sent there. But these schools still face the pressure of looking like a real school, which is referred to in Williamsons' discussion as "isomorphism," when something corresponds or has a similar form as another. He cites DiMaggio and Powell to capture how continuation schools are expected to conform to the expectations of a traditional high school:

In order to appear legitimate, organizations are expected to conform to structural prescriptions of an institution (DiMaggio \& Powell, 1983). In practice, this rigid conception of schooling does not always engage students in academics or keep them from dropping out. High school as an organization loses many students each year to a mismatch between prescribed practice and the very real needs of diverse youth. Despite 
the rational myth of standardized public education, one size does not fit all. (Williamson 2-3)

Due to the fact that the system of learning may not always match the formal structure of high school, "continuations schools serve as a less formal, decoupled setting for educational activities," in which "designing continuation education practice falls largely to the continuation educator or principal" (Williamson 3). The issue with this, however, is that not all continuation educators or administrators are specifically trained to deal with such a dynamic environment that differs so greatly from the traditional classroom space, and they may have cultural biases that they bring to their work. This is evident as one principal claims in a descriptive study, "California Continuation High Schools," a "typical" continuation high schooler is someone who has “fallen through the cracks. Generally, they're just kids who are sitting back, who don't do well academically, they're not interested, have poor attendance, or just have low skills in general" (Perez \& Johnson 6). As this study suggests, the principal's statement is not only assumptive and untrue but is extremely problematic in reaffirming the same toxic social construction of difference that surrounds continuation school students.

Williamson calls for a solution regarding the navigation "between the systems of mainstream public education and these social welfare institutions" in acknowledging that "continuation schools are deeply embedded in local contexts and rely on the individual leadership and personal networks of continuation educators and principals to coordinate resources and opportunities for students" (Williamson 11). Educators and administrators are the leaders of the classroom and the ones who have the potential for some of the greatest impact in continuation school students' lives, but there needs to be demand for an understanding of what 
kind of change needs to occur, and this can only be successfully accomplished if we reach the root of the issue, which lies in the conversation of social segregation.

The "California Continuation High Schools" descriptive study offers further insight on the outlook of educators and administrators within the continuation school space. Perez and Johnson note that their circumstances are not all about school, and that many students are referred to continuation settings based upon other factors of their life situation.

A lot of these kids are free and reduced lunch kids. A lot of them haven't had the opportunities for that preschool, parent-family nurturing. A majority of them have work issues, language issues, and little opportunity to get their skills to where they need to be. Maybe it's attendance, maybe it's family obligations, maybe it's that they sat in those chairs and just weren't interested because of the type of instruction. (Perez \& Johnson 7) A school leader offers their thoughts on observation based upon their experiences at a continuation school:

We were treating them like all other kids. We didn't know they had the mental issues, the drug issues, the behavior disorder issues. We're talking about kids coming out of incarcerations or mental institutions. Teachers were having a really hard time in their classrooms trying to manage these kids; they were being very disruptive (Perez \& Johnson 12).

The importance of this descriptive study is that it offers exposure of challenges within continuation schools, which allows for the space to discuss necessary improvements that ought to be systematically implemented in order to improve the function of continuation education.

In "The Continuation Schools," Ritchie Stevenson provides readers a 1934 perspective on continuation schools and the atmosphere in which they were constructed. Major changes were 
occurring within the academic system prior to the establishment of continuation schools. Boards of Education reduced teaching staff, cut funding and resources, and almost doubled the number of students for every class, leading to a great sense of demoralization for teachers as they were, on top of everything else, pressured into working for eight periods every school day. These changes impacted continuation schools in a particularly significant manner, for the services that were being eliminated "were extremely valuable to the continuation schools and to the guidance programs ... no time was allowed for counseling or for extramural visitation” (Stevenson 447).

The decision to increase the number of students per class "reduced efficiency of the teacher as a counselor and guide," essentially making it "impossible for a teacher to do individualized work with classes of this size" (Stevenson 447). It is no coincidence that these systemic changes continue to haunt the education system today, as they represent causal reasons that students are pipelined into continuation schools in the first place and are forcefully neglected as a result. Educators do not have the time or the resources to work one-on-one with the students that require extra attention, so those students who are not enabled in conforming to standardized educational standards face a manufactured sense of failure. Stevenson's work makes visible the early twentieth-century decisions that created problems impacting continuation school students today.

In the study "Redefining the Experiences of Students in Continuation High Schools," Edwin Hernandez argues that the segregation students sent to these institutions face on a daily basis makes it seemingly impossible for them to succeed in the way that they are expected to. He finds that students are considered problems rather than learners: handed off from one institution to another - treated as a 'problem' that nobody wanted to educate. As a result, the process of exclusion led to time out of the classroom and delays 
in (re)admission to school, both of which can lead to significant gaps in learning and difficulties in reintegrating back into school. (Hernandez 264)

Hernandez is pointing out that student segregation can be extremely harmful and counterproductive, for we want students who are failing to do better, yet we push them out of the environments that could potentially offer the most help if they were more suited to serve instead of project. Hernandez provides an example of a student named Esteban, who faced these circumstances: "I felt whenever I did something wrong they wanted me out even more, rather than trying to help me and fix the situation. They rather just transferred me and let another school deal with me and that's how it was for a good while" (Hernandez 264). Esteban's experience is, unfortunately, not unique, and I have had my own students share similar stories that lead them down the same pipeline, which becomes clear later in this study.

William Kratzert and Mona Kratzert, in "Characteristics of Continuation High School Students," conducted a case study to assess students' experiences in continuation schools in a variety of areas not found on the types of standardized tests that are typically administered. Their procedure consisted of randomly selecting 40 out of 190 students at a continuation high school. They found that $26 \%$ were minorities; the mean age was 17.3 ; and $56 \%$ were males. The students were provided with the Piers-Harris Children's Self-Concept Scale (Piers \& Harris, 1969) with the goal of determining "their feelings about themselves, and an author-prepared questionnaire which explored their feelings in a wide range of areas" regarding experiences, such

- like or dislike of continuation school placement

- number of school districts previously attended,

- family cohesiveness and communication with parents 
- communication with peers and staff,

- educational plans and aspirations,

- chemical dependency, and

- $\quad$ special education placement (Kratzert \& Kratzert 14).

The result of the study survey within the study revealed that the students' self-concepts "fell within average parameters" (Kratzert \& Kratzert 16). While many find this surprising due to the fact that continuation school students are considered to be "under-average" compared to students attending a regular school. The researchers came to the conclusion that being placed within the continuation school setting offered a boost in self-esteem among students after facing years of neglect and failure within their original space. Although this is a limited study, it offers insight into why the students may have been previously struggling within a regular school. The study claims that "lack of family unity, cohesiveness, and stability, as reported in psychological, educational, and sociological research, has an impact on academic achievement" (Kagan qtd. in Kratzert \& Kratzert 16). One of the saddest, yet harshest, realities is that although students may feel confident in their continuation school setting, "few will graduate from a ["regular"] public high school" (Kratzert \& Kratzert 16), which means that earlier intervention is needed in order to provide justice to these students' fullest capabilities and opportunity to succeed.

\section{Cultural Rhetorics Theory}

Cultural Rhetorics provides the theoretical framework for this study. When asking if academic success is the result of much more than a mastery of scholarly content, the cultural context must be included. Is it possible that academic success requires mastery of a much larger cultural system? With cultural rhetorics theory providing a context for the research, the most important 
part of the inquiry was listening to student stories and experiences. Therefore, the case study includes classroom participant-observation and student interviews as a means to hear the voices of those placed at a continuation school. The students can provide insight into the current secondary school system. In addition, the classroom teacher provide their perspective on the school curriculum and educational practice.

But where does cultural rhetorics fit into the picture, and what exactly is it? In "Our Story Begins Here: Constellating Cultural Rhetorics," the authors define culture as the "made up practices that accumulate over time and in relationship to specific places" (Powell et al.). Rhetoric refers to the study of meaning-making systems and how those systems are based upon certain practices, which cannot be separated from each other (Borchers \& Hundley 8). Thomas Rosteck defines rhetoric as "the use of language and other symbolic systems to make sense of our experiences, construct our personal and collective identities, produce meaning, and prompt action in the world (Rosteck 1). In essence, cultural rhetoric provides a foundation for working under the assumption that all cultures are rhetorical, and all rhetoric is cultural.

Cultural rhetorics scholar Michel de Certeau argues that many practices that establish cultures are concealed by dominant/majority rules and authorized practices, calling upon researchers to "determine the procedures, bases, effects, and possibilities of this collective activity' if we are to understand how the making of culture occurs through everyday practice instead of through official, sanctioned dominant acts of cultural installation" (de Certeau qtd. in Powell et al.). When we study education as a system, it becomes essential to acknowledge that we live within a postcolonial world that constructs not only certain communities but specific cultural systems as superior (or inferior) to others, which is directly related to the institutionalization of the "authorized practices" that de Certeau is speaking of. 
Now, I hope I did not lose you when I threw the whole "postcolonial" speech into the mixture, for arguably not all cultural rhetoric work has to work under decolonial practice. What is important to acknowledge, however, is that the "acceptance of multiple possibilities, multiple approaches" (Powell et al.) is all part of the study of decolonialism, so we cannot ignore it. The common misconception regarding colonial studies is that it only applies to discourse directly surrounding race, but we are most definitely living in a world that was founded by the social construction of difference - we just hide it under the more flowery term diversity. The study of decolonization matters greatly to oppressed communities because it reveals how individuals are continuously punished by Western ideologies, which includes the foundation of how we build our school systems and curriculum (Fanon qtd. in Maldonado-Torres).

I argue that in order to address the systemic issues that lurk throughout the school system, it is necessary to address the "practices that compose cultures" that are "hidden by dominant (aka, established) rules and authorized practices" (de Certeau qtd. in Powell et al.). The issue is not necessarily that current school standards and curriculum are not backed up by both historical and contemporary evidence: it is that that evidence is gathered through research conducted under a dominating form of culture that favors Westernized standardized ideology:

Remember, we're not on a mission to convert everyone to decolonial practice, or to our version of cultural rhetorics practices. We're visibilizing options and making those options available for others to use, and doing so as part of an attempt to intervene in and enlarge the acknowledged practices of our disciplinary community. (Powell et al.)

The authors of "Our Story Begins Here: Constellating Cultural Rhetorics," establish a metaphor between cultural rhetorics and a constellation, which they refer to as "a web of relations." This 
metaphor asks readers to understand cultural theory as a study of multiple possibilities with many approaches that "honors multiplicity" and the "multiplicities of orientations to scholarship that are possible" (Powell et al.).

We can use the constellation metaphor to discuss how we might view the school systems. The goal of this study is not to suggest that continuation schools should completely dismiss the standards that serve as a foundation for modern academia. Instead, it would be ideal to construct a curriculum that takes student culture into consideration, for student success in our school systems is currently based upon how talented students are in conforming to a standardized, dominant form of rhetoric that has taken over (the same kind of authority that de Certeau suggests). I have realized that when teaching at the secondary level it is impossible to completely escape standardized instruction; we live under laws and regulations that require educators to play under a certain rule set. The problem with these rules, however, is that they value the players that were meant to be professional players - the students who were raised and socialized to be successful. This does not mean, however, that we ought to give up; rather, we can work on "visualizing options and making those options available for others to use, and doing so as part of an attempt to intervene and enlarge the acknowledged practices" (Powell et al.) of our academic community, much like the way cultural rhetoric scholars address issues of power relations. If we can find a way to negotiate the means of set standards with our own intentions of an integrated curriculum that values multiplicity, then we may find success in enabling minoritized students to play the game better.

Cultural rhetorics can also provide deeper insights on how we relate and discuss continuation school students within scholarship, adding a much-needed area of study: "How we do scholarship matters a great deal to colonized peoples, especially those engaged in the huge 
task of decolonization" (Powell et al.). We spend a lot of time discussing scholarship in respect to the construction of school curriculum, but how often do we take the time to critique the rhetoric surrounding the biases of the way we address continuation schools? Almost every empirically, peer-reviewed article I found regarding continuation schools, among the few that there actually were, was quick to discuss the problems with the students or everything that goes wrong. While it is crucial to establish the negatives in order to ensure productive dialogue and to produce incentive for change, focusing on the students as problems creates the perception that there are only negative things to say about continuation schools and the students who are sent there.

If we can agree that Western methods of scholarship currently dominate the rhetoric constructed around continuation schools, then we can come to the conclusion that it would be necessary to "decolonize methodologies" to be more mindful of working with and for students relegated to continuation schools. Angela Haas continues this conversation within "Toward a Decolonial Digital and Visual American Indian Rhetorics Pedagogy." Haas explains how "secular education and the teaching of Western religious doctrine has served as the standard operating procedure in colonization of North, Central, and South America, and it continues to inform contemporary Western education ... and this colonial pursuit of knowledge transpires formally and informally and inside and outside the walls of academia" (Haas 188).

The most important aspect of the point Haas makes is that these systemic issues exist both inside and outside of the classroom and are interconnected in a multi-layered manner, much like the constellation metaphor regarding cultural rhetorics. Haas reinforces two important key notes. The first being that the operating systems of the States is influenced by colonialism in ways that 
are not always formal. This is important in acknowledging that the issues within this paper are difficult to pinpoint in terms of practical solutions because they are often conflicts that exist in the grey space between acknowledging sociocultural theory and the ability to establish tangible standards and curriculum. The second is that Western influences on education exist both in and outside of the classroom, revealing that this is a conversation that goes beyond what is occurring at continuation high schools but more so how we respect the attributions of cultural rhetoric at a more universal level.

Historically, academic pedagogy is wonderful when it comes to addressing the means of classroom theory in respect to psychological and behavioral development because they are discussions that are deemed to be backed up by scientific evidence. Acknowledging the place of cultural rhetorics, however, we can bring actual human experience and background into the conversation, which allows for the space of race and representation to be efficiently discussed. In “'Who Do You Think You Are?': Race, Representation, and Cultural Rhetorics in Online Spaces," Andre Brock explores how race impacts the practical experiences of students in their everyday academic life:

As I travel around the Web, I note the many ways that Blackness is articulated online. This behavior stems from my ever-present awareness of how I differ yet resemble cultural expectations of Black masculinity. As a youth, I was mocked for "acting White" because I loved to read, loved school, and "talked proper." As a Black graduate student, I was intensely uncomfortable with the limitations of being an "exceptional” Black placed upon me by my liberal professors, because I was aware that by labeling me as such they sought to separate me from my working class origins, speech patterns, and cultural 
perspectives in order to make me palatable for their consumption and indoctrination. (Brock 15)

Cultural identity does have an impact on student experience, and it is willfully ignorant to deny that it does so. 95\% of the students within the case study classroom identify as Hispanic, Mexican, ELL, or people of color, and these ethnic identities affect not only the way they see themselves but impact their actions as well. Everything starts at home: this is where the student learns the base of their social skills and the starting point to their cultural upbringing. It is essential to point out that many students of color are first generation learners, meaning that a great number of their parents are not fully acquainted with the formalized education system because of their own background and experiences. Yes, the education system does offer many resources for parents and students who need it, but resources are only as powerful as the user's ability to use them. Sometimes, it seems as if ELL resources exist for the sake of formality, and I am grateful that they exist as an attempt to help certain communities, but there is only so much that they can do to meet the needs of students. The issue is not always as simple as addressing communication barriers: the problem is deeply embedded within the colonial establishments that have been previously discussed. ELL resources are often just English translations of the same oppressive systems that segregate these groups in the first place.

A common perception of students in continuation schools is that they are affiliated with gangs. This is typically a judgmental note used to point out that the students are neglecting what is "best" for them or "looking" to get into trouble. What if, however, we looked deeper into the social construction of what gangs really are?

While gangs can be affiliated with concepts of drugs and violence, at the base level they are essentially cultural groupings. Brock observes that 
the experiences of Blacks in American civic life - de facto segregation and de jure equality ensure that conversations about how to be 'proper' Americans and 'real' Black people happen in private or commercial spaces where Blacks have time to congregate and talk. The only public outlets for these discourses of propriety and membership were Black newspapers and later, Black talk radio. (16)

I am not advocating for the development of gangs or justifying illegal behavior, but if we can acknowledge that gangs are ways in which students connect with people who are culturally like them, then it develops a space of empathy for us to understand these social issues at their roots. Maybe our students join gangs because it is an inclusive space where they are more comfortable because they do not feel that pressure to be the "proper" Americanized individual that the modern school system wants them to be. Continuation schools are a spatial representation of rejection - a place where students are put because they have been told that they do not belong in "regular" schools. We see gangs as a place of toxicity, but for those involved, they have been a place of cultural belonging because they are rejected by normalized constitutions.

A subcategory of cultural rhetorics that serves this discussion as well is embodied rhetorics, which is effectively expressed in "Reflections on/of Embodiment: Bringing Our Whole Selves to Class" (Smith et al.). Embodied rhetorics is the scholarly approach that advocates for a “"gesture to our bodies, our lives' in our work 'by calling to the surface at least some of the associations that [our] thinking passes through, associations evoked by [our] gender, race, class, sexual orientation, politics, and so on"” (Hindman \& Banks qtd. in Knoblauch 58). In order to practice embodied rhetorics, people are required to "tell their stories through reflection and give voice to their ontological, epistemological, and phenomenological experiences ... through reflection and the writing/creating of story" (Smith et al. 47). It is the method of embodied 
rhetorics that informs this case study. This method, as the authors explain, gives an individual opportunity to

explore my body ... how I might insert myself into the time and space of literature,

scholarship, and art. I realized that my performance had, up until recently, been about not drawing attention to myself. It was more about fitting in, going unnoticed, fading into the background. But now, with my body as my voice and my art, I realized that I am not queer because of my body. I am queer because I am not part of the background. I am a performance to be noticed, one that can and ought to affect others. I can spin in any direction I choose, and my audience can read me in any way that makes sense to them. In any case, I am a performance that must be appreciated. (Smith et al. 50-51)

This passage shows the potential ways in which students can see themselves and begin to build a specific type of identity based upon their placement in a continuation school. Their bodies are physically transferred to a segregated learning space, a space where they see themselves as dysfunctional figures that do not have a place among "normal" students. These are students who very much feel physically and psychologically part of the background at their original schools because they were not the ones getting praise or awards, so they bring this rejected sense of identity with them through the rest of their academic career, where it becomes a part of the formation of the self.

Before getting to the heart of this paper, I would like to discuss the importance of the methodology behind this project and why utilizing storytelling is the both most powerful and underrated form of conducting research. While I obviously see the value in other types of scholarly work, storytelling allows me an opportunity to explore depths of real life experiences, which is what writing in respect to cultural rhetoric is all about, for "those of us who love stories 
and want them, somehow, to count, to be seen as reliable and valuable records of experience (Perl et al). As "Storytelling as Scholarship" considers, however, there is a tension between using storytelling as a form of conducting "reliable" research because of the difficulty in maneuvering through potential subjectivity that personal stories inherently include. Storyteller scholars are caught in a constant battle of navigating the concepts of showing versus telling: "Researchers who tell stories, then, aim to strike a balance between narrative and analysis, to discover the right voice(s) to convey experiences of others along with their own, and in the words of Ruth Behar (1996), to make themselves 'vulnerable"” (Perl et al.), and I truly believe vulnerability is the key to discovering any type of truth. The minute we become too invested in formal methods of scholarship that we neglect the truths right in front of us is the moment where we forget that our students are more than just standardized statistics; they are humans with stories - stories that show us the flaws within our own system.

\section{The Study}

This study was conducted in a suburban school district within the district's "model" continuation school. The school district serves 28,000 K-12 students, with 218 grades 9-12 students enrolled in the continuation school. The study was conducted in the Spring of 2021 with both in-person and remote instruction due to the COVID-19 pandemic. The study included student and classroom teacher interviews as well as student writing samples and participantobservation notes. 


\section{Teachers' Perspective}

While student experiences are the main source of this project, it seems necessary that I include the instructor experience as well. Two classroom instructors were asked to speak about their general experiences within the classroom and how they approach education as a whole.

Sally, one of the main instructors I work under, is the reason this study exists because she allowed me to enter the space under her guidance. We have talked a great deal about the many ways in which the school system has failed our students and how these issues follow them into the continuation school system. So, what happens when you get a teacher that acknowledges the systemic issues of modern education? You get Sally. The most intriguing thing about Sally is that she has not been a teacher for a majority of her professional life, and in fact, did not express interest in teaching until nearly her 40s. This is important to acknowledge because we often assume the best educators are the ones with the most classroom experience, the most instruction time, and the most theory under their belt, but we fail to give credit to the importance of REAL LIFE experience in building one of the best foundations for a culturally empathetic instructor.

If there was one word I had to choose to describe Sally's teaching methodology, it would be exposure. Anytime I had an inquiry on why Sally chose a specific exercise for the lesson plan, she would tell me that exposure was one of the things that was actually within our control. We couldn't choose the curriculum, we couldn't choose if students didn't do their homework, and we couldn't choose whether they chose to go to college or not, but we could always ensure that they would be exposed to the necessary tools that they would need in the "real world."

People have challenged Sally's methodologies as a continuation school instructor, claiming the activities she chose were "too hard"- because kids like THESE could never do stuff like THAT. This, however, is the exact issue with the way that a lot of teachers approach 
continuation school students: instead of pushing them outside their comfort zone, they minimize the capacity of their intelligence and work to dumb down what already isn't working. Simple does not equate to better, and by not preparing our students for what they will experience outside of high school is irresponsible and, frankly, selfish. What Sally is doing in her classroom is attempting to break the toxic pattern of teaching that typically occurs for continuation school students, who are so used to being pushed away, to being told that they're not good enough to be in a "regular" school with the rest of society. If we continue to affirm this pattern within the continuation school space, it just further segregates them from societal normality. What is the point of sending them to another school and dumbing down math to the 2nd grade level? So you can pass them, give them a diploma, and send them on their way unprepared for the lives they will face?

We owe continuation students some sort of consistency when it comes to the way we establish our expectations for them. On one hand, we have educators who believe that the students are not capable of meeting any type of minimum standards, and then we have the "professionals" in the outside world that later tell the students that they are not "qualified" for a position because they have not been sufficiently prepared. This is why Sally's methodology is so valuable: exposure allows for the students to at least have certain skill sets in sight, for if they are never exposed to them, they may not even know they exist or the importance. As educators, our job is not to judge struggling students on their incapability but, rather, to find the means to ensure that they are provided access to the gates of success. In essence, we are striving to establish an academic space of equity within a society that lacks equality.

Sally once spoke to me about one of the more privileged schools in our area. "The motto is 'Winners win,"” she said. "But what if you're not winning? High school isn't great for 
everyone, and a lot of people feel like they're losing. What about them?" This captures the basis of this thesis. The modern high school system is in a constant cycle of rewarding those who demonstrate that they have been given the keys to success, and they know exactly which doors to put them into. "Ask a fish to climb a tree, and he's going to fail" captures the essence of continuation school issues.

Cassandra is another teacher that I have had the pleasure of working with, and I will always feel privileged to have had her as a mentor, for she has been in the classroom for nearly forty years. The most important thing I learned from working with Cassandra is the ability to humble my own ego. Fresh out of college, my mind was filled with eagerness and confidence in all the fresh theory I had learned, and I most definitely thought myself prepared to teach in an environment filled with such tremendous diversity. But learning how to work with Cassandra and all her years of experience taught me that I do not know everything there is to know about the classroom, no matter what private school education I got. Cassandra taught me that sometimes the only way to really learn about what works with students is to really learn how to work with them and not simply project my own thoughts upon them.

I will not ever forget the time I shared my concerns with Cassandra regarding our students: I had told her that I felt as if the curriculum was dull and insulting, for if I was in these students' positions, I probably wouldn't want to do the work either. She replied, "You know, I think our students are some of the brightest out there; they just aren't given the opportunity to show it." When students face academic failure at "regular" institutions and are sent to continuation schools, the programs are typically even more basic than what was provided in their home schools because it is assumed that the students' comprehension is below average. When this occurs, however, we completely neglect the conversation of motivation that occurs alongside 
mental stimulation. We segregate these students for not passing Algebra, so we punish them by giving them second grade math worksheets. Sure, there is some sense of self-accountability that one needs to have in order to succeed in school (i.e., "I don't care if it's boring: I still need to get it done"), but when the students struggle with self-motivation, why are we further discouraging them with implications of inability?

\section{A. Student Stories}

Let me continue with a couple of student stories:

\section{- George}

George is a student in the case study who had been working one-on-one with me, the classroom aide, on Algebra, a subject he really struggled with. Although many days had gone by without much explicit progress, each session I gently encouraged George, assuring him that he was getting better and better, assuring him through his apologies and hesitancy that I loved working with him no matter how many times we had to repeat things.

One day, my supervisor, the teacher of record for the case-study class, informed me that it would be George's last days to catch up on work in order to attempt to receive a passing grade. I was extremely anxious, for in respect to how much time we had spent together, I felt as if George and I had not gotten very far. I grew to be very fond of working with George even though he was still hesitant to work with me.

As the last days of the quarter approached, George stopped coming to class. I did not see it as noncompliance on his part; rather, I blamed myself: Where had I failed him? We want to believe that as trained educators that we are the masters of our field, that we know best when it comes to inspiring students to engage with the content. But let me tell you, no matter how much 
educational theory I had engaged with throughout my years in college nothing could change the fact that whatever I was doing for George was not working. I am confident that there is a stable middle ground between self-accountability and blaming yourself for things that you cannot control, but is it not our responsibility as educators to question and adjust our own methodology according to the needs of our students? It does not matter how good an educational theory sounds on paper or how many scholarly research papers can back it up if the end goal is not being met: to get these students to WANT to come to class and learn something. As scholars, we often get so caught up in the confidence of our own theory and those in our own bubble that reaffirm it that we forget that if a tree falls in the forest and no one is there to hear it, the noise is never heard.

On the last day of the quarter, however, I was surprised to see George log on to the private virtual classroom that I had set up to assist students on a one-to-one basis.

“I wasn't really planning on coming to class, but you and Ms. Jackson made me kind of want to do my work. Can you do some stuff with me?" he asked.

And there it was. I knew we had a long way to go to get George back on his feet, but it was a sign of hope; it was a sign that somewhere along the way, we had made George want to accomplish something in the classroom. I never doubted that he wanted to succeed, but I knew the real challenge was for George to see that he was worth so much more than he felt. In the midst of working together that day on Algebra, George stopped to tell me a story:

Do you know why I hate math?" he asked. "Because at my old school, I always asked for help, and ain't nobody ever do it. I always asked the teacher for help, and she would always tell me to wait 'one second' but never came. She would only help the kids that were already good at math. Me and Jack would just sit in the corner because she was 
always some type of mad and thought we were f*cking around. Then they would just keep putting us in the same math class over and over the next year."

This was the moment where I knew. My education within educational studies had prepared me to deal with segregation within the school system, but hearing it from George first hand hit me in an entirely different way. It wasn't only because my heart hurt for him and his experiences but because I knew exactly what type of circumstances he was talking about because during my own academic experiences, I was always the student on the other side: I was the student that knew what the teacher wanted to hear and was always welcomed with open arms for assistance. Although it is probably appropriate to claim that to some extent my academic success was a result of work ethic and discipline, I cannot forget that success is when an individual attributes hard work to a sense of opportunity. If educators are not ensuring that the standards of their classroom are met with equity, then we are denying students the chance to succeed to the best of their capabilities.

Simply being a part of a study was enough to significantly impact George's outlook on his academic career. Nearly every day after I asked George to participate in this thesis, he would ask me "How's that paper for school going?" I could tell that this was one of the first times in George's academic career where he felt valued, like this voice was actually being heard. I continued to work with George many times after our original sessions, and every single time we met with each other, he would ask about how my project was going. After including George in my study, I told him, "Well, I actually just finished writing your story, and I want to thank you for your inspiration because I most definitely could have not done it without you.”

If you could hear a smile in someone's voice, it would be on George during this exact moment. You could tell he was doing his best to maintain his tough guy persona, but the light 
shone through, “Oh, yeah? That's cool. I mean, I got a lot of things to say, you know, but sometimes, I don't know... I just feel like I'm wrong, and yeah. But that's cool." The most amazing part about George's story is that it provided a happy ending to a mini-saga of this part of his academic career, for things only got better from here on: George diligently worked with me on assignments and soon was getting top grades in his classes. Although he thanks me for the help, I attribute the credit to him. He was the one who decided to wake up every morning and ask for support, and he was the one who decided to get the work done. If we're being honest, my role in George's actual work completion was actually quite minimal, but the reason he feels as if it were so much more is because in his eyes all he needed was someone to open that door for him. It was never that George was incapable of passing his classes: he just wanted someone to care if he passed or not. Many continuation school students have spent years being told that they are not good enough or pushed under the rug to the point where a sense of positive affirmation can quite literally make or break their classroom experience. In an interesting cyclical process, me including George in the study made George feel valued, heard. That feeling, in turn, made a difference in his school success.

\section{- Paul}

Paul is another student that I served during the course of my instruction, and he is someone I hold dear to my heart because he is someone I can truly empathize with. During the pandemic, when we did not have many students in the classroom, Paul was one of the students that I had the pleasure of meeting in person. He was quiet and always kept his head in a hood, but he was always very sweet and polite when I talked to him. He was one of those people who you knew was kind at the core but had gone through a rough strand of life, and soon after meeting him I was informed that he had previously suffered from drug use and was battling depression. 
Very early on in the school year, Paul stopped coming in person, but he always showed up for online instruction. For a while, things were great: Paul and I often worked together and even joked around in the virtual classroom. As time progressed, however, Paul started logging in less frequently, and his list of missing assignments began to grow longer each day. Soon, I was making calls home nearly every day to see if he would be logging into the class, and it got to the point where Paul was failing every one of his classes. I often spoke to his mother, who was kind to me but admitted she did not know how to handle the situation because of the dark place Paul had fallen into.

After a couple of weeks, I was lucky enough to start seeing Paul more often; I guess he decided that he would rather show up than continue getting my nagging, concerned messages. Not only did he begin to show up more consistently, but he was engaging in class conversation and willing to work with me on catching up on his assignments. In English class, we had a few lessons that revolved around self-reflection and life journeys. During these discussions, Paul began to open up about his struggles. He shared that he felt trapped in a constant war with his mental health and was unsure how to manage stable relationships with both himself and those around him. His mental and social anxiety was so overwhelming that he could hardly handle focusing on school, and he often felt alone in his struggles. For the final project, we asked our students to write about a "journey of transformation," and I told Paul, who was intimidated by the writing process, to write as if he was having a conversation with me - not to fear the writing process or grading but to just write from the heart. This is an excerpt from what he produced:

Before you read this story or essay keep in mind my freshman year and the years before that $\mathrm{i}$ was the most happiness kid you could think of ... 
Its crazy how you dont know what you really have until its gone i mean at least for me, going into sophomore year i quit smoking and everything but i was still sick every doctor i went too didnt know what was wrong with me, that made me depressed because $\mathrm{i}$ thought to myself how am i going to get better ... My mindset was really bad it sads to say but all of this made me have so much hatred towards myself and the world so $\mathrm{i}$ abandoned it all, my friends, family, and its kinda weird but myself in a way $\mathrm{i}$ accepted my sick fate and gave up on everything, school, and my life ... it got really bad i pushed my whole family away, my mindset and my mental health was really bad i would look at the world and just everything in general in a negative way . when i was little my parents or friends would always say to look at life in a positive way but $\mathrm{i}$ thought how can i look at life positive when everything it getting worse for me until one night i started to look back at my old skate vidoes and just memories with my friends and that changed me completely

That night i said to myself ive had enough of this so the next morning i made myself eat and stay positive, even if $i$ was sick $i$ know if $i$ stayed like this $i$ wouldnt get any better and its better to try and fight for your life and happiness then to give up, so i forgave myself and i moved on, $\mathrm{i}$ looked at life in a positive way no matter what happens , i started skating more and going out more and reconnecting with my skate buddies and most importantly my family, sooner or later i did get better with myself and my body, at the moment im a little sick but every day im getting better i work out and go out alot more now , mental health is very important too so i cut down video games and i cut ties with people that are bad for me and i realize who my true friends are, i have alot more to say but yeah this is my story and i hope you enjoyed it $<3$ " 
Paul's situation teaches me a couple of things: first, the students often want to talk-they have something to say, and those things are crucial in the understanding of what matters to them. We assume that if students are quiet or not involved in classroom activities, they are not interested in contributing to academic discourse, but maybe they don't talk because we are not talking about the things that matter to them. I am not saying that students have to be in love with every topic that comes up in the classroom, but there are ways to make classroom discussions more relevant to their lives and the things that they are passionate about.

Maybe continuation school curriculum is a modified version of what already was not working at students' original schools without acknowledging that these students need something different. A simplified version of what already failed to work is not different: it is an insulting measure that is taken in order to try and get kids to pass so they can get a high school diploma and be on their way. As the Williamson article makes clear, continuation schools should not be "a cheap makeshift for the unfortunate, but rather a recognized and well-supported unit in democracy's public school system" (Waterfall qtd. in Williamson 1). For some students, it is simply enough to be given an assignment, and the motivation to get an " $\mathrm{A}$ " is enough for them to get the job done, but we already know these are the ones who are succeeding. I aspire for a curriculum that shows students that we care about the things they are going through and, as a result, would raise their interest in their studies and motivation to work.

Maybe schools need to start incorporating more relevant discussion and assistance for those who struggle with mental and emotional health. Having a counselor or school therapist is not the equivalent of classroom discourse because it needs to be a topic of conversation in order to destigmatize the assumption that mental health is something to be ashamed of - something 
that you have to go see a specialist for because you're an outsider and different than all those around you. If we can spend weeks trying to dissect what Shakespeare meant in Act 3, line 12, then we can afford to include scholarly texts within classroom curriculum that address mental health. Paul is dealing with feelings of depression, isolation, and the lack of will to live: how can we expect him to be concerned about the War of 1812 ?

C. The Interviews

Another part of the study included interviews. The following questions were asked of each student participant:

- Tell me a little bit about yourself, what schools you have attended and how you think you are doing at this high school as compared to your previous schools.

- Do you see a difference in the curriculum and instruction between your continuation school and your previous school? For example, are you studying the same material that you studied there? Explain.

- What are you particularly enjoying in your studies now?

- What lessons are relatable to your life? Give a couple of examples.

- What do you need from your school and teachers to learn?

- Describe how you are helped when you were struggling with a lesson?

- Do you feel like you have a voice in school? Are your thoughts valued? Explain why or why not. 


\section{- Paul}

When speaking of their continuation school within the interview, Paul claims, "This school is very good for me because it is easier and nice with the homework, and at other schools they push and pressure you too much." While I am glad Paul likes it at this school, I suppose the fact that "easy" is not necessarily always a positive thing because Paul also said that he was "not really studying anything important, to be honest" in response to asking him about the curriculum. The fact that Paul notes that the other schools pressure him too much gives possible cause of the fact that Paul did not find success at his first few schools, for he was already dealing with a tremendous amount of anxiety from personal issues, and the pressure he faced at school just made this worse.

One of the most admirable qualities of Paul is his ability to remain self-accountable. A lot of the time, people assume that students within the younger generation are becoming "soft" and are using mental health issues as a method to avoid responsibility. Paul, however, admits that there have been people who have tried to help him in his life, but he could not bring himself to listen. When asked if he was ever helped while struggling with a lesson, Paul said, "People tried to help me, but I didn't pay attention because I was going through stuff . . . some people did understand, but I didn't care to acknowledge them or what they had to say because I was just being stubborn." This is something that people do not understand about depression: it is not a choice that is made in order to establish an escape route away from responsibility; it is something that takes over the entirety of your mind and emotions, affecting your behavior and the choices that you make. People may have tried to help Paul with class lessons, but how many people helped Paul in the way that he needed it? 
When I asked Paul if he felt like he had a voice in school and if his thoughts were valued, hoping to find out more about those who may have been able to reach out to him regarding his true internal struggles, his response was, "I feel like I have a voice, but I'd rather keep them to myself unless someone asks. People just don't ask." This may be the root of the issue: educators and admins assume that we know the answers to define the methodology to help students, but maybe we aren't asking the right type of questions. At the end of the day, Paul was still pushed out of a "regular" institution. Can we really claim to have helped him? Paul concluded his interview by saying that although he felt this response was "kinda off topic," he wanted to learn more about the "FBI or the army" because he desired to "learn more about future opportunities other than college."

\section{- Arthur}

Arthur is a student that always put a smile on my face when he walked in the door. He was one of the first students I met when I started working at the school, and I was heartbroken when his father showed up after several consecutive days of absences to tell us that Arthur was missing and on the streets. I don't think I saw Arthur for a couple months after that. We never really talked much, but it was one of those things where I didn't realize how much of an impact having students within my classroom could make, especially with only a couple showing up in person during this time.

Then one day, Arthur came back to school. I later found out that he had only returned by order of court because he had an ankle bracelet, but I was happy to have him back nonetheless. He had always been pretty quiet, but I noticed he was making more of an effort to talk to me. Since we were often the only two in the classroom when Sally (the main instructor) was in meetings or co-teaching in other classrooms, we got into some fairly personal, deep 
conversations about his home life, the things he had been through, and his views on the education system.

I remember one day in particular where Arthur and I got deep into discussion surrounding the school-to-prison pipeline, and I started pacing around the classroom because I was so infuriated by the subject. When Arthur noticed I had become quiet for a while, he asked, "Are you thinking about everything?" I nodded my head sullenly. He looked me straight in the face and said, "There's no point-you can't change any of it. It is what it is, and you just have to deal with it. Life is just sh*t like that sometimes, and no one cares."

I was not shocked by Arthur's response, but I felt his disappointment. This was one of those moments where I realized no matter what kind of educators they have continuation school students are facing an uphill battle that they have already convinced themselves that they are losing. Imagine trying to motivate students to learn when all the thoughts in their head tell them that they have systematically been set up to fail—that they have no chance at success because society has already decided that they are not worthy. When I asked if he felt like he had a voice in school, his response was "Nah, I feel like we don't matter."

The rest of Arthur's interview pretty much affirmed these thoughts, and when I asked him about his school history and how he felt about continuation schools, he responded, "I went to a couple schools before, but I was always getting kicked out of school. This school is different, like a negative difference. It feels like this school is trying to make you feel like the scum of the earth, like you are the bad kids."

When questioned about the curriculum and its engagement level, Arthur said, "The work is so easy here. It's good so I can pass, but it's 'downgraded' so everyone can do it." He also found that there was "nothing really interesting" about what he was learning, nor anything that 
contributed to his life, and that, “They just gave me whatever classes. It doesn't matter if I like it or not: they just want me to graduate." Finally, Arthur wished he could study more topics that he felt like "he was good at" or "something more interesting."

- Stacy

Stacy kept me company for most of my first quarter at the school because she was the only one that attended in-person instruction due to the Covid Pandemic. The first thing I noticed about Stacy was that she loved talking to any person that showed interest in listening to her. She wasn't the type to go up to someone and ask for help, but she was always looking for an open ear. She was one of those students who you knew didn't get the attention at home and was always looking elsewhere for it.

One day, I was sitting at my desk and Stacy asked, "Do you want to read something I wrote for another class?" Although I made a mental note that Stacy ought to stay focused on completing her work for the class we were currently in, I realized it was never a good idea to shut someone down, especially when they want to share a creative work with you-if a student wants to share something with you, be flattered and interested. I took Stacy's laptop and sat down to read the essay, which was titled "La historia de mi vida y de mi depresión" ("The History of My Life and of My Depression”). I was taken aback by the personal subject, but at the same time was not genuinely shocked because these are the types of things I knew the students were facing in their everyday lives.

Here are some excerpts from Stacy's work:

"I really liked life before going to school, I felt free and happy. I was in my own world, my own thoughts ... Going to school is hard for me, it always has been but I still manage to wake up every morning and go to school to get the education I need for my future." 
"I grew up in the hood you could say there was a lot of gang members that lived there but I never got into any gangs or tried to get involved. A few gangbangers were my friends and they would always buy me candy or ice cream. They were good people in my eyes."

"When nobody was there for me when I need someone to be there to cry on to guide me when I was lost when I felt alone, empty, worthless, depressed, helpless, meaningless, no point in life, suicidal, I stopped loving myself and started hating myself. I forgot what happiness was every time I tried to be happy, It was always taken away from me. Being alone at 14 sucked so much it felt like a living hell. Waking up every morning not finding a reason to even try for anything no motivation to keep living anymore I just wanted to die. I wanted to fall into a deep deep sleep and never wake up."

Much like with the previous discussion with Paul, Stacy's experience points to the subject of mental health, which is often dismissed by educators who may assume mental health issues are an excuse that students use in order to get out of completing work. These problems, however, are real, and it does not matter what you believe them to be because it seems ridiculous to criticize a student for not being able to keep up with an Algebra lesson if all that is on their mind is not wanting to be alive. This is why listening to student stories in terms of research and establishing the best possible learning environment is essential, for this is what will show us why certain students may not be performing well, and it shows us that kicking students out of "regular" schools can be a problematic method of addressing student failure: it does not address the root of the issue, it simply segregates them based upon their level of trauma and their ability 
to handle it. When asked about what else she would like to study in school, Stacy said, "I would like to learn more about how to handle my depression because I feel like no one has ever explained it to me."

Stacy's commentary indicates that growing up among certain cultural influences ("gangs") can cause complications. While society framed gangs around violence and drug use, a lot of these kids just see those who are gang-involved as normal people and peers that could turn into potential friends. Although Stacy says that she had not particularly fallen into one of these gangs herself, like other students, it goes to show that students are attracted to groups that they feel like they can find a sense of belonging within, which is how Stacy felt when she was isolated from her past schools. When I asked about her experience with her past schools compared to her current one, she said,

"I would get bullied so much to the point where I would do anything so I won't go to school. I sometimes would even act sick to not go to school. I was scared to go to school, I skipped school for a whole week once. I hated school so much I would cry so bad in the shower because I didn't like how I would get bullied just because I was a nice, tall. chubby person."

Following this, Stacy commented upon the nature of continuation schools in that "Distancing myself from everyone feels good but then it feels really lonely." I find it intriguing yet sad that Stacy sees the process of being sent to a continuation school as being "distanced" from others instead of feeling like she is still part of a communal school system. It is, in fact, problematic because it shows that the students feel like they do not belong, contributing to a greater sense of isolation, negatively impacting their mental health and ability to accept themselves as functioning members of society. These are not feelings that go away after graduation: they form 
the labels that students wear in the outside world and shape the way they view themselves to others within the professional environment.

\section{- Matt}

My experience with Matt is one that I'll never forget because it was the first time it really hit me how real the struggles of these students were. The thing is, I had become comfortable with the concept that the students were facing some of the darkest battles in the world but had not fully emotionally prepared myself to hear the rawness behind their stories - stories that were current and happening each day that Matt went home after school. There is often a cognitive dissonance that often occurs between teachers and the relationship they have with their students in the sense that we often pride ourselves in being there for our students, but that is support that is often limited to the classroom space. The students still have to go home and fight a variety of their own battles.

I was asked to walk Matt to the counselor's office on a number of occasions. As we walked, I would attempt to make small talk with him. Although he was extremely quiet, he was always polite and did not imagine he had faced the things that he had in his past. I asked Matt why he was having trouble getting his work complete and if there was anything I could do to help him. He told me that had a lot of problems at home, and his overseers would often not allow him to do his homework because there were "more important" chores to do around the house. Matt would often come to school during his free hours outside of class to get work done.

The difference between Matt and some of the other students I interviewed was that, despite all the strenuous conditions he had faced, he was highly optimistic and appreciative of his opportunity to go to school. When I asked him to compare his previous schools to the current one, he said, "this school genuinely cares about its students . . my previous schools sometimes 
did not care about me." When I asked which school lessons were currently relatable to his life, he responded, 'Learning that I should speak to people more because if I wouldn't have asked for help, then I wouldn't have gotten help from my home situation and would not have had the opportunity to be where I am now." Matt also said that he would like to take AP classes, an opportunity he does not have at the continuation school, and he would like to have options to learn about "intriguing concepts" such as "psychology."

We often criticize students who are failing for being "lazy" and neglective of their work, while Matt's story shows us that, in reality, there are various factors that attribute to students staying on top of their work. Matt wanted to be successful; he wanted to do more than what was being offered to him at the continuation school, but he had been labeled and placed into a category of students because of his personal issues. The thing is, Matt is capable of doing more than what is currently being asked of him in his studies. I have seen his work, and I have seen the way he is able to develop his thoughts in writing — writing that definitely has a place in higher education, such as college.

After conducting Matt's interview, I sat with him on a bench for the remainder of lunch. We shared stories regarding our battles with depression, anxiety, and other things that come along with the journey through adolescence. I remember turning to him and saying, "I feel like I've known you my entire life.” I didn’t realize why I felt that way at first, but I realized that I saw a younger version of myself in him. The thing is, I had done a lot of the things Matt had done and shared a lot of the same battles he had, but the difference is that $I$ had gotten the help I needed-I was privileged enough to have had people to take care of me during my hardships and the financial resources to see professionals. Even when I would skip classes, no one was kicking me out with the amount of tuition I was paying. With the continuation school students, however, 
few of them have the kind of resources, opportunities for assistance, or even the family support to get what they need. They come from schools who see them as disposable—as nuisances who can't conform to standards, a problem to send elsewhere.

The interviews provided an opportunity to talk with students about their academic experience. The fact that all the students wanted to engage in discussion about both their past and present engagement in school demonstrates that they are very much interested in being within a space of learning, which shows that they do not fit the "careless" figure that many people make them out to be. Every student claimed that either the things they were learning in school did not seem purposely relevant to their lives or that the things that they were learning were simply too easy— too easy in a way that is insulting, offering no inspiration for further improvement because the standards are already on the floor.

One of the most relevant themes among the students is that they wanted more from their education system, and they wanted the opportunity to learn about other topics that expanded beyond the limited curriculum that is offered. They wanted to learn about things that were interesting to their life, which I think is more than fair considering the purpose of being in the classroom is to learn. Incorporating curriculum relating to a more diverse study of culture that takes into consideration varying perspective on social issues can be effective, as well as more present classroom conversation regarding mental health. When we shove students into spaces of isolation because they are not excelling at the things that we tell them are important, then we are essentially implying that it does not matter what is important to them.

The most important theme that the study revealed is that continuation school students want so, so badly for someone to listen. There was not a single student that refused discussion nor hesitated when I asked them if they wanted to be involved in this study, and a lot of them 
told me that no one had ever asked them about their thoughts at all. They didn't even care where the study was going or if it was anonymous or not; you could tell that they were just excited to be involved in something that they could contribute to. Imagine if students were involved in authentic activities as part of their curriculum, imagine if they were given opportunities to not only be a part of their education system but were more frequently given the chance to express their voices among topics that are crucial to social justice.

\section{Conclusion}

Now, we have yet to still discuss the title of this paper: "Why Are We Still Reading About Rosa Parks?" It was one of my students who raised this question in response to an English class discussion that was being conducted while reading a Black history novel. Although she noted the importance of learning about the historical foundations of social advocacy, she was curious to know why we couldn't talk about modern subjects, such as "Black Lives Matter" or the events going on around us that were relevant to their current lives.

This was the beginning of this project. It was not just because this student had expressed interest in learning about something new but because it pointed out the flaws of our current system. We push these narratives of historical oppression unto our students but do not provide them with the space to talk about what they really want to talk about; Instead, we continuously punish them for not being able to effectively engage with a curriculum that was established by who knows who at some administrative level. How can we, as educators, claim that lessons about social justice are important when the education system offers no justice to its socially marginalized students? We pressure them to memorize the details of people of color of the past but do not respect the students of color that are right in front of us. 
I have found that the continuation school curriculum does not effectively address the selfdescribed needs and interests of the students. These are students that need a curriculum that is built upon empathy and takes into consideration the diverse backgrounds that they come from. Since the study reveals the sense of confidence that the interviewed students got when they received the opportunity to participate in the creation of a college thesis, it may be valuable to allow continuation school students to take part in more meaningful projects-projects that they can be proud to be a part of. Doing meaningful work can be extremely impactful and can assist in developing greater academic motivation. Also, the opportunity for students to share and write personal narratives can be a powerful addition to the classroom so that they will have further chances to share their stories.

I challenge educators and administrators, especially those working in continuation schools, to step outside what we traditionally "know" to work in the classroom and turn these values on their side. We are not here to fight for the sustainability of our own teaching methods as if we are trying to prove that two plus two is four; we are here in these types of environments to transcend the boundaries that have already proved to be failing these students.

This study focuses on observations concerning the systemic flaws prohibiting our students from flourishing. There is much more work to be done. This study offered observations with a small sample size, and it would be useful to engage with additional students at different continuation settings in order to see if we can find patterns in a larger scale to strengthen the viability of the results.

My biggest wish is that his project inspires more relevant conversation surrounding continuation school education. This project demonstrates that the students struggling under current academic conditions have so much to say that provides value to how we approach 
education. The most important thing that the current research surrounding continuation school education showed me, in fact, is that there is not enough research at all. There are thousands of scholarly articles regarding classroom theory and pedagogy, but there are so many blank pages that are yet to be filled by our students. Storytelling not only brings us deeper into the world of our students; it brings us closer to the truth, for what could possibly show us more profoundly what works for students than hearing what comes straight from their voices? 


\section{Bibliography}

Bizzaro, Resa Crane. Survivance, Sovereignty, and Story: Teaching American Indian Rhetorics. University Press of Colorado, 2015.

Brock, André. “'Who Do You Think You Are?': Race, Representation, and Cultural Rhetorics in Online Spaces.” Poroi, vol. 6, no. 1, July 2009, pp. 15-35, doi:10.13008/21512957.1013.

Hernandez Edwin. "Redefining the Experiences of Students in Continuation High Schools: A Narrative Profile of a Latino Youth.” High School Journal, vol. 100, no. 4, July 2017, pp. $264-81$.

Kamrath, Barry. "Avoiding Dropout: A Case Study of an Evening School Alternative Program." Planning \& Changing, vol. 48, no. 3/4, Jan. 2019, pp. 150-72.

Kelly, Deirdre M. Last Chance High: How Girls and Boys Drop in and Out of Alternative Schools. Yale University Press, 1993.

Knoblauch, Abby. "Bodies of Knowledge: Definitions, Delineations, and Implications of Embodied Writing in the Academy." Composition Studies, vol. 40, no. 2, 2012, pp. 5065.

Kratzert, William F, and Mona Y. Kratzert. "Characteristics of Continuation High School Students" Adolescence, vol. 26, no. 101, Spring 1991, pp. 13- 27.

Maldonado-Torres, Nelson. "Frantz Fanon and the Decolonial Turn in Psychology: From Modern/Colonial Methods to the Decolonial Attitude.” South African Journal of Psychology, vol. 47, no. 4, Dec. 2017, pp. 432-441.

Perez, Lynne, and Joseph Johnson. California Continuation High Schools: A Descriptive Study. The National Center for Urban School Transformation. Feb. 2021. 
Perl, Sondra, et al. "Storytelling as Scholarship: A Writerly Approach to Research.” English Education, vol. 39, no. 4, 2007, pp. 306-325.

Powell, Malea, Daisy Levy, Andrea Riley-Mukavetz, Marilee Brookes-Gillies, Maria Novotny, and Jennifer Fisch-Ferguson. "Our Story Begins Here: Constellating Cultural Rhetorics” Enculturation. 25 October 2014.

Rosteck, Thomas. “Approaching the Intersection: Issues of Identity, Politics, and Critical Practice." In At the Intersection: Cultural Studies and Rhetorical Studies. Thomas Rosteck, ed. Gulford Press, pp. 1-24.

Smith, Trixie, Katie Manthey, John Gagno, Ezeliel Choffel, Wonderful Faison, Scott Secrist, and Phil Bratta. "Reflections on/of Embodiment: Bringing Our Whole Selves to Class." Feminist Teacher, vol. 28, no. 1, 2017, pp. 45-63.

Stevenson, J. Ritchie. “The Continuation Schools.” The Journal of Educational Sociology, vol. 7, no. 7, [American Sociological Association, Sage Publications, Inc.], 1934, pp. 447-51.

Williamson, Devon. Legislative History of Alternative Education: The Policy Context of Continuation High Schools. The Gardner Center, 2008. 